\title{
Acquired Pure Red Cell Aplasia
}

National Cancer Institute

\section{Source}

National Cancer Institute. Acquired Pure Red Cell Aplasia. NCI Thesaurus. Code C70548.

A disease characterized by normocytic, normochromic anemia, low hematocrit,

reticulocytopenia and selective erythroid hypoplasia. It can occur as a chronic or acute

form; the former is predominantly seen in adults and the latter in children. Pathogenesis

involves immune dysfunction with antibodies directed ag ainst erythroid precursor cells or erythropoietin, or due to T-cell mediated suppression of erythropoiesis. 